\title{
ESTIMASI NILAI AVERAGE VALUE AT RISK PADA SAHAM PORTOFOLIO DENGAN MENGGUNAKAN METODE ANALISIS KOMPONEN UTAMA
}

\author{
Ni Luh Nikasari ${ }^{1}$, Komang Dharmawan ${ }^{2 \S}$, I Gusti Ayu Made Srinadi ${ }^{3}$ \\ ${ }^{1}$ Jurusan Matematika, FMIPA - UniversitasUdayana [Email: niikasari94@ gmail.com] \\ ${ }^{2}$ Jurusan Matematika, FMIPA - UniversitasUdayana [Email: k.dharmawan@unud.ac.id] \\ ${ }^{3}$ Jurusan Matematika, FMIPA - UniversitasUdayana [Email: srinadi@unud.ac.id] \\ ${ }^{\S}$ Corresponding Author
}

\begin{abstract}
There are several methods that can be used to measure the risk of a portfolio of stocks. One of them is Average Value at Risk (AVaR). The purpose of this study is to implement Principal Component Analysis (PCA) to select stocks to be incorporated in the portfolio and also to compare the AVaR of the portfolio when the stocks selected using PCA and selected using mean-variance method. The data we used are the closing price of the stocks BBCA, BDMN, ICBP, INTP, CPIN, KLBF, GGRM, MNCN, SMCB, and SGRO. The selected stocks using PCA are BBCA, CPIN, INTP and, MNCN with AVaR is $1.0971 \%$ for $90 \%$ confidence level and for $95 \%$ confidence level is $1.1432 \%$ whereas by using mean variance method, it is found that BDMN, GGRM, ICBP, and SMCB have to be incorporated in the portfolio with AVaR is $1.3314 \%$ for $90 \%$ confidence level and $1.4263 \%$ for $95 \%$ confidence level.
\end{abstract}

Keyword: Principal Component Analysis, Average Value at Risk, Portfolio Markowitz.

\section{PENDAHULUAN}

Pada era globalisasi saat ini pengukuran dan pengelolaan risiko pada data finansial telah mengalami kemajuan yang sangat pesat dan lumrah dilakukan dalam manajemen risiko. Seorang investor akan membentuk portofolio saham untuk mengelola suatu risiko. Hal yang harus dipertimbangkan dalam mengolah dan mengukur suatu risiko pada portofolio adalah korelasi antara saham-saham yang akan membentuk portofolio tersebut. Koefisien korelasi menunjukan bagaimana suatu variabel bergerak bersama dengan variabel lain. Namun pada kasus finansial hal ini sangat sulit untuk dilakukan oleh para investor sehingga diperlukan metode analisis komponen utama.

Analisis Komponen Utama (AKU) merupakan metode analisis peubah multi yang bertujuan memperkecil dimensi peubah asal sehingga diperoleh peubah baru (komponen utama) yang tidak saling berkorelasi tetapi menyimpan sebagian besar informasi yang terkandung dalam peubah asal (Morrison, 1990).Teknik Analisis Komponen Utama ini dapat dikatakan setara dengan analisis regresi karena dapat menentukan dan menemukan peubah yang berkorelasi optimal.

Pengukuran dan pengelolaan risiko memerlukan alat ukur. Salah satu alat ukur risiko yang dipopulerkan oleh J.P. Morgan dan dianggap sebagai metode standar dalam mengukur risiko pasar adalah Value at Risk (VaR). VaR merupakan ukuran risiko yang umum digunakan untuk manajemen risiko finansial dikarenakan konsepnya sederhana, mudah dalam perhitungan, serta dapat diterapkan secara langsung (Yamai \& Yoshiba, 2005). Namun, VaR memiliki sejumlah kekurangan yang diakui oleh para ahli di bidang finansial antara lain $\mathrm{VaR}$ hanya mengukur persentil dari distribusi keuntungan atau kerugian tanpa memperhatikan setiap kerugian yang melebihi tingkat $\mathrm{VaR}$, dan $\mathrm{VaR}$ tidak koheren karena tidak memiliki sifat sub-additive 
(Artzner, et al., 1999). VaR tidak dapat digunakan sebagai alat ukur risiko yang akurat. Sebagai alternatif untuk mengatasi kelemahan pada VaR adalah Average Value at Risk (AVaR)

AVaR merupakan alat ukur risiko yang memiliki beberapa keunggulan dibandingkan dengan VaR. Salah satu keunggulan dari AVaR yang tidak dimiliki oleh $\mathrm{VaR}$ adalah $\mathrm{AVaR}$ memenuhi semua aksioma mengenai sifat risiko yang koheren dan konsisten dalam kaitannya dengan investor yang bersifat risk-varse. Selain itu AVaR memiliki interpretasi intuitif, yaitu dalam hal komputasi dan portofolio optimal (Dharmawan, 2015).

Penelitian ini membahas estimasi nilai Average Value at Risk (AVaR) pada saham portofolio dengan menggunakan metode analisis komponen utama . Berikut diberikan konsepkonsep dasar dari perhitungan AVaR menggunakan metode analisis komponen utama.

\section{TINJAUAN PUSTAKA}

\section{Return}

Return adalah hasil yang diperoleh investor dari investasi dengan cara menghitung selisih antara jumlah yang diterima dan jumlah yang diinvestasikan dengan mengabaikan dividen (pembagian laba). Return dapat dirumuskan sebagai berikut (Sunaryo, 2007):

$$
\mathrm{R}_{\mathrm{t}}=\ln \left(\frac{s_{t}}{s_{t-1}}\right)
$$

dengan $R_{t}$ menyatakan tingkat pengembalian saham pada periode ke- $t, S_{t}$ menyatakan harga saham pada periode ke- $t$, dan $S_{t-1}$ menyatakan harga saham pada periode ke- $t-1$.

\section{Teori Portofolio Markowitz}

Teori portofolio Markowitz didasarkan atas pendekatan mean (rata-rata) dan variance (varians), dengan mean merupakan pengukuran tingkat return dan varians merupakan pengukuran tingkat risiko (Jogiyanto, 2003). Teori Portofolio Markowitz disebut juga Metode Mean Variance. Pada pembentukan portofolio optimal dengan model Markowitz, portofolio optimal yang terbentuk merupakan pilihan dari berbagai sekuritas dari portofolio efisien
Investor dapat melakukan sejumlah kombinasi alokasi dana pada masing-masing saham untuk memperoleh sejumlah portofolio yang diinginkan. Menurut Husnan (2003) berdasarkan sejumlah portofolio yang telah dibentuk, dapat ditentukan portofolio optimal dengan cara optimasi sebagai berikut:

$$
\text { Minimumkan: } \sum w_{i}^{2} \sigma_{i}^{2}+\sum \sum w_{i} w_{j} \sigma_{i j}
$$
dengan batasan:

$$
\begin{array}{ll}
\text { 1. } & \sum w_{i}=1 \\
\text { 2. } & \sum w_{i} \mu_{i}=E\left(R_{P}\right) \\
\text { 3. } & w_{i} \geq 0, \quad i=1,2,3
\end{array}
$$

\section{Analisis Komponen Utama}

Analisis Komponen Utama bertujuan untuk menyederhanakan variabel yang diamati dengan cara mereduksi dimensinya. Keunggulan metode Analisis Komponen Utama ini diantaranya adalah dapat menghilangkan korelasi secara bersih tanpa harus mengurangi jumlah variabel asal. Misalkan terdapat vektor acak $\mathbf{X}$ dengan $E(X)=\mu, \operatorname{Var}(X)=\Sigma$.

$$
\begin{aligned}
\mathrm{X} & =\left(\begin{array}{c}
X_{1} \\
X_{2} \\
\vdots \\
X_{P}
\end{array}\right) \\
\operatorname{Var}(\mathrm{X})=\Sigma & =\left(\begin{array}{cccc}
\sigma_{1}^{2} & \sigma_{12} & \cdots & \sigma_{1 p} \\
\sigma_{21} & \sigma_{2}^{2} & \cdots & \sigma_{2 p} \\
\vdots & \vdots & \ddots & \vdots \\
\sigma_{p 1} & \sigma_{p 2} & \ldots & \sigma_{p}^{2}
\end{array}\right)
\end{aligned}
$$

Melalui persamaan karakteristik matriks $\operatorname{Var}(\mathrm{X})=\Sigma$ dapat diperoleh nilai eigennya yaitu $\lambda_{1} \geq \lambda_{2} \geq \cdots \geq \lambda_{p} \geq 0$ dan vektor eigennya yaitu $e_{1}, e_{2}, \ldots, e_{p}$ (Yulianto \& Putriana, 2013).

Pembentukan komponen utama merupakan kombinasi linier dari vektor variabel $x$ yang memiliki varians maksimum (di antara semua kombinasi linear), sehingga menyumbang sebanyak variasi dalam data sebanyak mungkin. Kombinasi linier yang terbentuk dapat dinyatakan dalam bentuk (Yulianto \& Putriana, 2013) :

$$
\mathrm{Y}_{\mathrm{P}}=e_{P 1} X_{1}+e_{P 2} X_{2}+\cdots+e_{P P} X_{P}
$$

Proporsi keragaman total yang dijelaskan oleh komponen utama ke- $i$ adalah:

$$
=\frac{\lambda_{i}}{\lambda_{1}+\lambda_{2}+\cdots+\lambda_{p}} \quad i=1,2, \ldots, p
$$




\section{Value at Risk (VaR)}

Value at Risk (VaR) merupakan sebuah pengukuran estimasi kerugian maksimum yang akan diperoleh selama periode waktu (time priode) tertentu dalam kondisi pasar normal pada tingkat kepercayaan (confidence interval) tertentu. VaR pada tingkat kepercayaan $\alpha$ dan selang waktu $t$ dapat diformulasikan sebagai (Hubbert, 2012):

$$
\operatorname{VaR}_{\alpha}=\mu+\sigma \Phi^{-1}(\alpha) \sqrt{t}
$$

dengan $\mu$ adalah rata-rata saham dan $\sigma$ adalah standar deviasi saham.

\section{Average Value at Risk (AVaR)}

Average Value at Risk (AVaR) merupakan alternatif utama dalam pengukuran risiko yang berfungsi untuk mengurangi masalah yang terjadi pada VaR. AVaR dengan tingkat kepercayaan $\alpha \in[0,1]$ dan fungsi dari distribusi pengembaliannya diasumsikan memiliki fungsi kontinyu, maka persamaannya dapat ditulis sebagai berikut (Rachev \& Svetlozar):

$$
\begin{aligned}
\operatorname{AVaR}_{\alpha}(X) & =-\frac{1}{\alpha} \int_{0}^{\alpha} F_{X}^{-1}(t) d t \\
= & -E\left(X \mid X \leq \operatorname{VaR}_{\alpha}(X)\right)(7)
\end{aligned}
$$

dengan $F_{X}^{-1}$ adalah invers suatu fungsi distribusi dari $\alpha$.

\section{METODE PENELITIAN}

Data yang digunakan dalam penelitian ini adalah data sekunder, yaitu data harga penutupan (closing price) dari 10 saham, yaitu BBCA, BDMN, ICBP, INTP, CPIN, KLBF, GGRM, MNCN, SMCB, SGRO. Informasi saham dapat diakses pada (www.finance.yahoo.com) dengan periode yang diambil adalah 3 tahun (2013 sampai dengan 2016). Analisis data dalam penilitian ini menggunakan bantuan program MATLAB 2009.

Langkah-langkah analisis data dalam penilitian ini yaitu: (1) mengumpulkan data harga penutupan masing-masing saham; (2) menghitung tingkat pengembalian (return) dari masing-masing saham; (3) mencari nilai statistik deskriptif dari masing-masing return yang diperoleh; (4) melakukan proses analisis komponen utama; (5) membentuk portofolio optimal; (6) estimasi nilai AVaR dari portofolio saham; (7) melakukan interpretasi dari hasil yang diperoleh.

\section{HASIL DAN PEMBAHASAN}

Langkah pertama yang dilakukan adalah mengumpulkan data closing price dari sepuluh saham. Setelah data dari sepuluh saham terkumpul, maka akan dihitung nilai return dari masing-masing saham dengan menggunakan persamaan (1).

Sebagai contoh perhitungan yang dilakukan adalah menghitung nilai $R_{t}$ saham Bank Central Asia Tbk (BBCA) pada saat $t=1$ sebagai berikut:

$$
\begin{aligned}
R_{1} & =\ln \left(\frac{15050}{15725}\right) \\
& =-0.04387381 .
\end{aligned}
$$

Melalui proses yang sama untuk nilai $R_{t}$ $(2 \leq t \leq 37)$ dihitung dengan menggunakan software Matlab 2009.

Berdasarkan nilai return yang telah diperoleh

\begin{tabular}{|c|c|c|c|c|}
\hline Sahzm & Mean & $\begin{array}{l}\text { Stanciand } \\
\text { Deniation }\end{array}$ & Stremess & Kintasis \\
\hline$B B C A$ & $-0,0135$ & 0,0471 & -12858 & 39466 \\
\hline BDMN & $-0,0025$ & 0,1006 & 0,2712 & 3,2518 \\
\hline CPN & $-0,0028$ & 0,1216 & 0,0557 & 3,3928 \\
\hline GGRM & $-0,0190$ & 0,0661 & $-0,1921$ & 2,1931 \\
\hline ICBP & $-0,0206$ & 0,0692 & 0,2507 & 2,5982 \\
\hline INT & $-0,0036$ & 0,0840 & 0,1067 & $256+2$ \\
\hline $\mathrm{KLBF}$ & $-0,0118$ & 0,0632 & 0,9108 & 46532 \\
\hline MANoN & 0,0061 & 0,1458 & 0,0466 & 5,6738 \\
\hline SGRO & $-0,0028$ & 0,0931 & 0,2731 & 3,4253 \\
\hline$S M C B$ & 0,0218 & 0,0986 & 0,1097 & 26457 \\
\hline
\end{tabular}
dari masing-masing saham dapat diketahui nilai nilai statistik deskriptif dari sepuluh saham dapat dilihat pada Tabel 1.

Tabel 1. Nilai Statistik Deskriptif

Pada Tabel 1 dapat dilihat bahwa return saham BBCA dan GGRM memiliki kemencongan ekor yang lebih memanjang ke kiri dengan kata lain nilai skewness dari saham BBCA dan GGRM bernilai negatif sedangkan return saham BDMN, CPIN, ICBP, INTP, KLBF, MNCN, SGRO, SMCB memiliki kemencongan ekor yang lebih memanjang ke 
kanan dengan kata lain skewness dari sahamsaham tersebut bernilai positif. Selain itu, nilai kurtosis pada saham BBCA, BDMN, CPIN, KLBF, MNCN, dan SGRO memiliki keruncingan leptokurtik sedangkan kurtosis pada saham GGRM, ICBP, INTP, dan SMCB memiliki keruncingan platykurtik.

\section{Penerapan Metode Analisis Komponen Utama}

Analisis Komponen Utama merupakan salah satu metode yang dapat diaplikasikan pada data finansial yang berupa portofolio untuk menentukan variabel - variabel yang efektif digunakan dalam berinvestasi.

Pada penilitian ini terdapat sepuluh saham yang kemudian akan dipilih empat saham untuk membentuk portofolio saham. Adapun hasil perhitungannya sebagai berikut:

(i) Berdasarkan nilai eigen dan vektor eigennya maka dapat dibentuk Komponen Utama. Komponen Utama yang pertama merupakan kombinasi linier terbobot dari peubah asal yang mempunyai varians terbesar. Komponen Utama kedua juga merupakan kombinasi linier terbobot dari peubah asal dengan varians terbesar kedua dan antara kedua komponen utama tersebut tidak berkorelasi, demikian seterusnya. Kombinasi linier yang terbentuk dapat dinyatakan dalam bentuk:

$\mathrm{Y}_{1}=$

$$
\begin{aligned}
& (0.37746) \mathrm{BBCA}+(0.38474) \mathrm{BDMN}+ \\
& (0.30733) \mathrm{CPIN}+(0.25059) \mathrm{GGRM}+ \\
& (0.31869) \mathrm{ICBP}+(0.34317) \mathrm{INTP}+ \\
& (0.40935) \mathrm{KLBF}+(0.10996) \mathrm{MNCN}+ \\
& (0.27853) \mathrm{SGRO}+(0.27512) \mathrm{SMCB}
\end{aligned}
$$

$\mathrm{Y}_{2}=$

$$
\begin{aligned}
& (-0.2376) \mathrm{BBCA}+ \\
& (-0.23963) \mathrm{BDMN}+ \\
& (-0.05147) \mathrm{CPIN}+ \\
& (0.48238) \mathrm{GGRM}+(-0.44835) \mathrm{ICBP}+ \\
& (0.05602) \mathrm{INTP}+(-0.14731) \mathrm{KLBF}+ \\
& (0.19214) \mathrm{MNCN}+(0.51649) \mathrm{SGRO}+ \\
& (0.3482) \mathrm{SMCB}
\end{aligned}
$$$$
\mathrm{Y}_{10}=
$$$$
(-0.04638) \mathrm{BBCA}+
$$

$$
\begin{aligned}
& (-0.49388) \mathrm{BDMN}+ \\
& (0.12236) \mathrm{CPIN}+ \\
& (-0.33767) \mathrm{GGRM}+ \\
& (0.36652) \mathrm{ICBP}+(-0.09047) \mathrm{INTP}+ \\
& (0.15592) \mathrm{KLBF}+ \\
& (-0.08265) \mathrm{MNCN}+ \\
& (0.63262) \mathrm{SGRO}+(-0.22597) \mathrm{SMCB}
\end{aligned}
$$

Proporsi keragaman total yang dijelaskan dari masing-masing komponen utama dapat dilihat pada Tabel 2.

Tabel 2 Proporsi Keragaman Total

\begin{tabular}{|c|c|}
\hline $\begin{array}{l}\text { Komponen } \\
\text { Utama Ke-i }\end{array}$ & Proporsi (\%) \\
\hline 1 & 32.6084 \\
\hline 2 & 18.8678 \\
\hline 3 & 12.5283 \\
\hline 4 & 9.2879 \\
\hline 5 & 8.1175 \\
\hline 6 & 5.989 \\
\hline 7 & 4.9084 \\
\hline 8 & 3.5624 \\
\hline 9 & 2.869 \\
\hline 10 & 1.2613 \\
\hline
\end{tabular}

(ii) Berdasarkan sepuluh komponen utama yang terbentuk, maka yang dijadikan acuan dalam memilih saham adalah komponen utama yang ke sepuluh. Karena komponen utama yang ke sepuluh merupakan kombinasi linear dengan nilai proporsi keragaman total terkecil. Pemilihan empat saham untuk membentuk portofolio dengan cara melihat nilai koefisien yang mendekati nol pada persamaan komponen utama yang ke sepuluh. Saham yang dipilih adalah Saham BBCA, CPIN, INTP, dan MNCN.

\section{Menentukan Portofolio Optimal}

Pada pembentukan portofolio optimal ini didasarkan pada tahapan-tahapan yang terdapat pada portofolio Markowitz. Pemilihan saham yang digunakan dalam pembentukan portofolio optimal dapat dilihat berdasarkan saham-saham yang terpilih melalui proses analasis komponen utama dan juga dapat langsung dilakukan pada proses portofolio Markowitz dengan melihat koefisien korelasi dari sepuluh saham. 


\section{Menentukan Portofolio Optimal Berdasarkan Saham yang Terpilih dari Proses Metode Analisis Komponen Utama}

Pada pembentukan portofolio optimal ini saham yang digunakan adalah saham BBCA, CPIN, INTP, dan MNCN. Berikut hasil pengolahan data dan pembentukan portofolio optimal:

a. Expected Return Saham

Expected return saham merupakan nilai yang menggambarkan bagaimana keadaan harga saham dapat diperoleh dengan menjumlahkan seluruh return saham kemudian dibagi dengan periode penelitian. Hasil perhitungan expected return saham disajikan pada Tabel 3 .

Tabel 3. Expected Return Masing-masing Saham

\begin{tabular}{|c|l|c|}
\hline No & Saham & Expected Return \\
\hline 1 & BBCA & -0.0135 \\
\hline 2 & CPIN & -0.0028 \\
\hline 3 & INTP & -0.0036 \\
\hline 4 & MNCN & 0.0061 \\
\hline
\end{tabular}

b. Standar Deviasi Saham

Standar deviasi saham mempresentasikan volatilitas saham. Hasil perhitungan standar deviasi masing-masing saham dapat dilihat pada Tabel 4.

Tabel 4. Standar Deviasi Masing-masing Saham

\begin{tabular}{|c|l|c|}
\hline No & \multicolumn{1}{|c|}{ Saham } & Standar Deviasi \\
\hline 1 & BBCA & 0.0471 \\
\hline 2 & CPIN & 0.1216 \\
\hline 3 & INTP & 0.0840 \\
\hline 4 & MNCN & 0.1458 \\
\hline
\end{tabular}

c. Matriks Korelasi Saham

Unsur - unsur yang terdapat pada matriks ini berupa koefisien korelasi dari sekumpulan saham. Matriks korelasi antar saham dapat dilihat pada Tabel 5.

Tabel 5 menunjukkan bahwa saham yang memiliki nilai korelasi negtif hanya korelasi antara saham CPIN dan MNCN, artinya pergerakan harga sahamnya adalah tidak searah atau berlawanan yaitu ketika harga saham yang satu naik makan harga saham yang lain akan turun, begitu juga sebaliknya. Dari keempat korelasi yang terjadi, korelasi antara saham BBCA dan INTP memiliki koefisien korelasi positif terbesar.

Tabel 5. Koefisien Korelasi Antar Saham

\begin{tabular}{|c|l|c|c|c|c|}
\hline \multirow{2}{*}{$\mathrm{N}_{\theta}$} & \multirow{2}{*}{ Saham } & \multicolumn{4}{|c|}{ Koefisien Korelasi } \\
\cline { 3 - 6 } & & BBCA & CPN & NTP & MNCN \\
\hline 1 & \multirow{2}{*}{ BBCA } & 1 & 0,2508 & 0,2246 & 0,3052 \\
\hline 2 & CPN & 0,2508 & 1 & 0,1421 & $-0,1324$ \\
\hline 3 & INTP & 0,3246 & 0,1421 & 1 & 0,1448 \\
\hline 4 & MNCN & 0,3052 & $-0,1324$ & 0,1448 & 1 \\
\hline
\end{tabular}

d. Komposisi Dana Saham

Berdasarkan konsep dasar Teori Portofolio Markowitz, peneliti memasukkan proporsi dana pada masing-masing saham, sehingga diperoleh sejumlah portofolio yang diinginkan. Pada penelitian ini dibentuk 20 portofolio dari empat saham, yaitu saham BBCA, CPIN, INTP, MNCN. Hasil komposisi dana saham dari 20 portofolio yang dibentuk disajikan pada Tabel 6 .

Tabel 6. Komposisi Dana Masing-masing Saham

\begin{tabular}{|c|c|c|c|c|}
\hline \multirow{2}{*}{$\begin{array}{c}\text { No. } \\
\text { Portofolio }\end{array}$} & \multicolumn{4}{|c|}{ Komposisi (\%) } \\
\cline { 2 - 5 } & BBCA & CPIN & INTP & MNCN \\
\hline 1 & 80,7286 & 4,96454 & 13,1358 & 1,17102 \\
\hline 2 & 73,8782 & 6,95527 & 15,6269 & 3,53965 \\
\hline 3 & 67,0278 & 8,94601 & 18,1179 & 5,90828 \\
\hline 4 & 60,1774 & 10,9367 & 20,6089 & 8,27691 \\
\hline 5 & 53,3271 & 12,9275 & 23,0999 & 10,6455 \\
\hline 6 & 46,4767 & 14,9182 & 25,5909 & 13,0142 \\
\hline 7 & 39,6263 & 16,909 & 28,082 & 15,3828 \\
\hline 8 & 32,7759 & 18,8997 & 30,573 & 17,7514 \\
\hline 9 & 25,9255 & 20,8904 & 33,064 & 20,1201 \\
\hline 10 & 19,0751 & 22,8812 & 35,555 & 22,4887 \\
\hline 11 & 12,2247 & 24,8719 & 38,0461 & 24,8573 \\
\hline 12 & 5,37434 & 26,8626 & 40,5371 & 27,226 \\
\hline 13 & 0 & 28,504 & 40,3774 & 31,1185 \\
\hline 14 & 0 & 28,8734 & 30,5666 & 40,5599 \\
\hline 15 & 0 & 29,2429 & 20,7559 & 50,0013 \\
\hline 16 & 0 & 29,6123 & 10,9451 & 59,4426 \\
\hline 17 & 0 & 29,9817 & 1,13427 & 68,884 \\
\hline 18 & 0 & 20,8186 & 0 & 79,1814 \\
\hline 19 & 0 & 10,4093 & 0 & 89,5907 \\
\hline 20 & 0 & 0 & 0 & 100 \\
\hline & & & & \\
\hline
\end{tabular}


e. Expected Return Portofolio dan Risiko Portofolio

Berdasarkan komposisi dana saham pada Tabel 6, maka dapat diperoleh tingkat pengembalian portofolio dan risiko portofolio. Hasil perhitungan expected return portofolio dan risiko portofolio akan disajikan pada Tabel 7.

Tabel 7. Expected Return Portofolio dan Risiko Portofolio

\begin{tabular}{|c|c|c|}
\hline $\begin{array}{c}\text { No. } \\
\text { Port }\end{array}$ & $\begin{array}{c}\text { Expected Return } \\
\text { Portofolio }\left(\boldsymbol{E}\left(\boldsymbol{R}_{\boldsymbol{p}}\right)\right) \\
(\%)\end{array}$ & $\begin{array}{c}\text { Risiko } \\
\text { Portofolio }\left(\boldsymbol{\sigma}_{\boldsymbol{p}}\right) \\
(\%)\end{array}$ \\
\hline 1 & $-1,143204806$ & 4,537768337 \\
\hline 2 & $-1,051037147$ & 4,558439417 \\
\hline 3 & $-0,958869488$ & 4,61989775 \\
\hline 4 & $-0,866701828$ & 4,720550539 \\
\hline 5 & $-0,774534169$ & 4,857962168 \\
\hline 6 & $-0,68236651$ & 5,029120433 \\
\hline 7 & $-0,59019885$ & 5,230713633 \\
\hline 8 & $-0,498031191$ & 5,459371278 \\
\hline 9 & $-0,405863532$ & 5,711843946 \\
\hline 10 & $-0,313695872$ & 5,985118598 \\
\hline 11 & $-0,221528213$ & 6,276478701 \\
\hline 12 & $-0,129360554$ & 6,583523525 \\
\hline 13 & $-0,037192894$ & 6,910992875 \\
\hline 14 & 0,054974765 & 7,441212238 \\
\hline 15 & 0,147142424 & 8,21118284 \\
\hline 16 & 0,239310084 & 9,160648158 \\
\hline 17 & 0,331477743 & 10,23979945 \\
\hline 18 & 0,423645402 & 11,48685769 \\
\hline 19 & 0,515813062 & 12,95545605 \\
\hline 20 & 0,607980721 & 14,57980283 \\
\hline
\end{tabular}

\section{Menentukan Portofolio Optimal dengan Portofolio Markowitz}

Pembentukan portofolio optimal pada proses ini akan memilih 4 saham dari 10 saham yang ada berdasarkan nilai koefisien korelasi terkecil dari sepuluh saham yang ada. Berikut hasil pengolahan data dan pembentukan portofolio optimal:

a. Expected Return Saham

Expected return saham merupakan nilai yang menggambarkan bagaimana keadaan harga saham dapat diperoleh dengan menjumlahkan seluruh return saham kemudian dibagi dengan periode penelitian. Hasil perhitungan expected return saham disajikan pada Tabel 8.
Tabel 8. Expected Return Masing-masing Saham

\begin{tabular}{|c|l|c|}
\hline No & \multicolumn{1}{|c|}{ Saham } & Expected Return \\
\hline 1 & BBCA & -0.0135 \\
\hline 2 & BDMN & -0.0025 \\
\hline 3 & CPIN & -0.0028 \\
\hline 4 & GGRM & -0.0180 \\
\hline 5 & ICBP & -0.0206 \\
\hline 6 & INTP & -0.0036 \\
\hline 7 & KLBF & -0.0118 \\
\hline 8 & MNCN & 0.0061 \\
\hline 9 & SGRO & -0.0028 \\
\hline 10 & SMCB & 0.0218 \\
\hline
\end{tabular}

b. Standar Deviasi Saham

Standar deviasi saham mempresentasikan volatilitas saham. Hasil perhitungan standar deviasi masing-masing saham dapat dilihat pada Tabel 9.

Tabel 9. Standar Deviasi Masing-masing Saham

\begin{tabular}{|c|l|c|}
\hline No & \multicolumn{1}{|c|}{ Saham } & Standar Deviasi \\
\hline 1 & BBCA & 0.0471 \\
\hline 2 & BDMN & 0.1006 \\
\hline 3 & CPIN & 0.1216 \\
\hline 4 & GGRM & 0.0661 \\
\hline 5 & ICBP & 0.0692 \\
\hline 6 & INTP & 0.0840 \\
\hline 7 & KLBF & 0.0632 \\
\hline 8 & MNCN & 0.1458 \\
\hline 9 & SGRO & 0.0931 \\
\hline 10 & SMCB & 0.0986 \\
\hline
\end{tabular}

c. Matriks Korelasi Saham

Unsur - unsur yang terdapat pada matriks ini berupa koefisien korelasi dari sekumpulan saham. Saham yang memiliki nilai koefisien korelasi yang mendekati nol yaitu antara saham BDMN dengan saham SMCB dan antara saham GGRM dengan saham ICBP dengan nilai korelasi sebesar 0.0074 dan 0.017. Matriks korelasi antar empat saham yang dipilih pada portofolio ini akan disajikan pada Tabel 10. 
Tabel 10. Koefisien Korelasi Antar Saham

\begin{tabular}{|c|l|c|c|c|c|}
\hline \multirow{2}{*}{ No } & \multirow{2}{*}{ Saham } & \multicolumn{4}{|c|}{ Koefisien Korelasi } \\
\cline { 3 - 6 } & & BDMN & GGRM & ICBP & SMCB \\
\hline 1 & BDMN & 1 & 0,0959 & 0,4550 & 0,0074 \\
\hline 2 & GGRM & 0,0959 & 1 & $-0,0171$ & 0,3557 \\
\hline 3 & ICBP & 0,4850 & $-0,0171$ & 1 & 0,0414 \\
\hline 4 & SMCB & 0,0074 & 0,3557 & 0,0414 & 1 \\
\hline
\end{tabular}

Tabel 10 menunjukkan bahwa saham yang memiliki nilai korelasi negtif hanya korelasi antara saham ICBP dan GGRM, artinya pergerakan harga sahamnya adalah tidak searah atau berlawanan yaitu ketika harga saham yang satu naik makan harga saham yang lain akan turun, begitu juga sebaliknya. Dari keempat korelasi yang terjadi, korelasi antara saham ICBP dan BDMN memiliki koefisien korelasi positif terbesar.

\section{d. Komposisi Dana Saham}

Berdasarkan konsep dasar Teori Portofolio Markowitz, peniliti memasukkan proporsi dana pada masing - masing saham, sehingga diperoleh sejumlah portofolio yang diinginkan. Pada penilitian ini dibentuk 20 portofolio dari empat saham, yaitu saham BDMN, GGRM, ICBP, dan SMCB. Hasil komposisi dana saham dari 20 portofolio yang dibentuk disajikan pada Tabel 11 .

Tabel 11. Komposisi Dana Masing-masing Saham

\begin{tabular}{|c|c|c|c|c|}
\hline \multirow{2}{*}{$\begin{array}{c}\text { No. } \\
\text { Portofolio }\end{array}$} & \multicolumn{4}{|c|}{ Komposisi (\%) } \\
\cline { 2 - 5 } & BDMN & GGRM & ICBP & SMCB \\
\hline 1 & 4.427084 & 43.59069 & 41.60772 & 10.37451 \\
\hline 2 & 6.458801 & 40.54209 & 38.82565 & 14.17345 \\
\hline 3 & 8.490519 & 37.4935 & 36.04359 & 17.97239 \\
\hline 4 & 10.52224 & 34.4449 & 33.26153 & 21.77133 \\
\hline 5 & 12.55395 & 31.39631 & 30.47947 & 25.57027 \\
\hline 6 & 14.58567 & 28.34771 & 27.6974 & 29.36921 \\
\hline 7 & 16.61739 & 25.29912 & 24.91534 & 33.16815 \\
\hline 8 & 18.64911 & 22.25052 & 22.13328 & 36.96709 \\
\hline 9 & 20.68082 & 19.20193 & 19.35122 & 40.76603 \\
\hline 10 & 22.71254 & 16.15333 & 16.56915 & 44.56497 \\
\hline 11 & 24.74426 & 13.10474 & 13.78709 & 48.36391 \\
\hline 12 & 26.77598 & 10.05614 & 11.00503 & 52.16285 \\
\hline 13 & 28.80769 & 7.007546 & 8.222965 & 55.96179 \\
\hline 14 & 30.83941 & 3.958951 & 5.440903 & 59.76073 \\
\hline 15 & 32.87113 & 0.910356 & 2.65884 & 63.55967 \\
\hline 16 & 31.19501 & 0 & 0 & 68.80499 \\
\hline 17 & 23.39626 & 0 & 0 & 76.60374 \\
\hline 18 & 15.5975 & 0 & 0 & 84.4025 \\
\hline 19 & 7.798752 & 0 & 0 & 92.20125 \\
\hline 20 & 0 & 0 & 0 & 100 \\
\hline & & & & \\
\hline & & 0 & 0 & 0 \\
\hline
\end{tabular}

e. Expected Return Portofolio dan Risiko Portofolio

Berdasarkan komposisi dana saham pada Tabel 11, maka dapat diperoleh tingkat pengembalian portofolio dan risiko portofolio. Hasil perhitungan expected return portofolio dan risiko portofolio akan disajikan pada Tabel 12.

Tabel 12. Expected Return Portofolio dan Risiko Portofolio

\begin{tabular}{|c|c|c|}
\hline $\begin{array}{c}\text { No. } \\
\text { Port }\end{array}$ & $\begin{array}{c}\text { Expected Retuon } \\
\text { Portofolio }\left(\boldsymbol{E}\left(\boldsymbol{R}_{\boldsymbol{p}}\right)\right) \\
(\%)\end{array}$ & $\begin{array}{c}\text { Risiko } \\
\text { Portofolio }\left(\boldsymbol{\sigma}_{p}\right) \\
(\%)\end{array}$ \\
\hline 1 & $-1,426322024$ & 4,624182585 \\
\hline 2 & $-1,236573444$ & 4,640777628 \\
\hline 3 & $-1,046824863$ & 4,690210466 \\
\hline 4 & $-0,857076283$ & 4,771460599 \\
\hline 5 & $-0,567327702$ & 4,882940006 \\
\hline 6 & $-0,477579122$ & 5,022636237 \\
\hline 7 & $-0,287830541$ & 5,188270545 \\
\hline 8 & $-0,09808196$ & 5,377446656 \\
\hline 9 & 0,09166662 & 5,587774033 \\
\hline 10 & 0,281415201 & 5,81695879 \\
\hline 11 & 0,471163781 & 6,062862798 \\
\hline 12 & 0,660912362 & 6,323535867 \\
\hline 13 & 0,850660942 & 6,597227541 \\
\hline 14 & 1,040409523 & 6,882384863 \\
\hline 15 & 1,230158103 & 7,177641423 \\
\hline 16 & 1,419906684 & 7,493811557 \\
\hline 17 & 1,609655265 & 7,925630346 \\
\hline 18 & 1,799403845 & 8,477544032 \\
\hline 19 & 1,989152426 & 9,127793873 \\
\hline 20 & 2,178901006 & 9,856937703 \\
\hline
\end{tabular}

\section{Estimasi Nilai Average Value at Risk}

AVaR merupakan salah satu pengukuran risiko yang dapat digunakan sebagai alternatif untuk mengukur suatu risiko. Pada Tahap ini dihitung estimasi nilai $\mathrm{AVaR}$ pada portofolio saham yang dipilih berdasarkan metode analisis komponen utama, yaitu saham BBCA, CPIN, INTP, dan MNCN dan juga estimasi nilai AVaR pada portofolio saham yang dipilih berdasarkan portofolio markowitz, yaitu saham BDMN, GGRM, ICBP, dan SMCB. Tingkat kepercayaan yang digunakan pada peniliitian ini yaitu $90 \%$ dan 95\%. Estimasi Nilai AVaR dari dua portofolio yang terbentuk dapat dilihat Tabel 13 . 
Tabel 13. Estimasi Nilai Average Value at Risk (AVaR)

\begin{tabular}{|c|c|c|c|}
\hline \multirow{4}{*}{ VaR } & \multirow{2}{*}{ Metode } & \multicolumn{2}{|c|}{ Tingkat Kepercayaan } \\
\cline { 2 - 4 } & $\begin{array}{c}\text { Analisis } \\
\text { Komponen } \\
\text { Utama }\end{array}$ & $1,0050 \%$ & $95 \%$ \\
\cline { 2 - 4 } & $\begin{array}{c}\text { Portofolio } \\
\text { Markowitz }\end{array}$ & $1,1417 \%$ & $1,3314 \%$ \\
\hline \multirow{4}{*}{ AVaR } & $\begin{array}{c}\text { Analisis } \\
\text { Komponen } \\
\text { Utama }\end{array}$ & $1,0971 \%$ & $1,1432 \%$ \\
\cline { 2 - 4 } & $\begin{array}{c}\text { Portofolio } \\
\text { Narkowitz }\end{array}$ & $1,3314 \%$ & $1,4263 \%$ \\
\hline
\end{tabular}

\section{Interpretasi Hasil}

Hasil perhitungan estimasi nilai AVaR dengan menggunakan metode Analisis Komponen Utama dan portofolio Markowitz dapat dilihat pada Tabel 13. Interpretasi yang bisa diberikan adalah untuk nilai AVaR dengan menggunakan metode Analisis Komponen Utama pada tingkat kepercayaan $90 \%$ dan $95 \%$ secara berturut turut sebesar $1,0971 \%$ dan $1,1432 \%$ yang berarti kerugian yang mungkin dialami oleh investor satu bulan ke depan pada tingkat kepercayaan $90 \%$ dan $95 \%$ secara berturut turut sebesar $1,0971 \%$ dan $1,1432 \%$ dari aset yang diinvestasikan, interpretasi yang sama berlaku untuk nilai AVaR menggunakan portofolio Markowitz. Semakin besar nilai AVaR menunjukkan portofolio yang terbentuk lebih agresif. Seorang investor yang bersifat risk averse akan cenderung memilih portofolio dengan risiko yang rendah sedangkan investor yang bersifat risk seeker akan memilih portofolio dengan risiko yang lebih tinggi karena investor tersebut meyakini risiko yang tinggi akan diikuti dengan expected return portofolio yang tinggi pula.

Misalnya dengan memiliki modal sebesar Rp.1.000.000,00, kerugian yang mungkin dialami pada satu bulan ke depan dengan tingkat kepercayaan $90 \%$ dengan menggunakan metode analisis komponen utama adalah sebesar Rp.10.971,00 dan untuk yang menggunakan portofolio Markowitz, kerugian yang mungkin dialami sebesar Rp.13.314,00. Pada tingkat kepercayaan $95 \%$ dengan menggunakan metode analisis komponen utama kerugian yang mungkin dialami pada satu bulan ke depan adalah sebesar Rp.11.432,00 dan untuk yang menggunakan portofolio Markowitz kerugian yang mungkin dialami sebesar Rp.14.263,00.

\section{KESIMPULAN DAN SARAN}

Berdasarkan perhitungan dan pembahasan yang telah diuraikan pada bab sebelumnya, diperoleh kesimpulan bahwa:

1. Data-data saham yang digunakan dalam penelitian ini yaitu BBCA, BDMN, ICBP, INTP, CPIN, KLBF, SGRO, SMCB, GGRM, MNCN. Melalui metode analisis komponen utama dipilih empat saham untuk membentuk portofolio optimal yaitu, saham BBCA, CPIN, INTP, dan MNCN dengan nilai AVaR pada selang kepercayan $90 \%$ yaitu sebesar $1,0971 \%$ dan untuk selang kepercayaan $95 \%$ nilai AVaRnya sebesar $1,1432 \%$.

2. Estimasi nilai AVaR dengan menggunakan metode analisis komponen utama lebih kecil dibandingkan nilai AVaR dengan portofolio Markowitz. Nilai AVaR yang lebih tinggi pada portofolio Markowitz mengindikasikan portofolio yang lebih agresif.

Adapun hal-hal yang disarankan peneliti untuk penelitian selanjutnya adalah menambahkan variabel yang digunakan dalam pembentukan portofolio optimal serta membandingkan hasilnya dengan penelitian ini.. Selain itu untuk penelitian selanjutnya dapat menggunakan variabel selain saham, seperti obligasi, interest rate, dan variabel pasar lainnya.

\section{DAFTAR PUSTAKA}

Artzner, P., Delbaen, F., Eber, J.-M. \& Heath, D., 1999. Coherent Measures of Risk. Mathematical Finance, 9(3), pp. 203-228.

Dharmawan, K., 2015. Estimasi Nilai AVaR Menggunakan Model GJR dan Model GARCH. Jurnal Matematika, V(2), pp. 117127.

Hubbert, S., 2012. Essential Mathematics for Market Risk Management. 2nd ed. USA: Hoboken, N.J. : Wiley. 
Husnan, S., 2003. Dasar-Dasar Teori Portofolio dan Analisis Sekuritas. Yogyakarta: Unit Penerbitan dan Percetakan AMP YKPN.

Jogiyanto, 2003. Teori Portofolio dan Analisis Investasi. ketiga ed. Yogyakarta: BPFE.

Morrison, D. F., 1990. Multivariate Statistical Method. 3rd ed. Singapore: McGrawHill Publishing Company .

Rachev \& Svetlozar, T., 2007. Advanced Stochastic Models, Risk Assessment, and Portfolio Optimization : The Ideal Risk, Uncertainty, and Performance Measures.. USA: Wiley.

Sunaryo, T., 2007. Manajemen Risiko Finansial. Kedua ed. Jakarta: Salemba Empat.

Yamai, Y. \& Yoshiba, T., 2005. Value-at-Risk Versus Expected Shortfall: A Practical Perspective. Jurnal of Banking \& Finance, Volume 29, pp. 997-1015.

Yulianto, S. \& Putriana, U., 2013. Analisi Komponen Utama (AKU) Untuk Pengelompokan Area Pelayanan dan Jaringan (APJ) Daerah Jawa Tengah dan D.I.Yogyakarta. Buletin Median, Volume vi, pp. 30-39. 